\title{
Combining Ability Studies in Tomato (Solanum lycopersicum L.) in Mid Hills of Uttarakhand
}

\author{
A.M. Veena ${ }^{1}$, Ajaya Paliwal $^{2}$, J.C. Thilak ${ }^{1}$, Himani Rana ${ }^{1}$ and S.C. Pant ${ }^{1}$ \\ ${ }^{1}$ Department of Vegetable Science, ${ }^{2}$ Department of Crop Improvement, College of \\ Horticulture, VCSG UUHF, Bharsar \\ *Corresponding author
}

\section{A B S T R A C T}

\section{Keywords}

General combining ability, Specific combining ability, Non-additive, Half diallel fashion

Article Info

Accepted:

15 January 2019

Available Online:

10 February 2019
The investigation was carried out to study the general combining ability and specific combining ability in genotypes and their cross combinations for yield and quality characters. Six tomato lines, fifteen cross combinations derived from $6 \times 6$ half diallel fashion with Arka Rakshak as check cultivar/line were taken for the experiment. Study revealed the predominance of non-additive gene effects for number of fruit clusters per plant, number of fruits per cluster, number of fruits per plant, fruit length, fruit breadth, marketable fruit yield per plant, shelf life, pericarp thickness, TSS, ascorbic acid and whitefly infestation. AVTO-9001 $\times$ Sioux and Solan Lalima $\times$ Sioux were the best specific cross combinations which has high positive significant effects for plant height, number of fruit clusters per plant, fruit length, fruit breadth, average fruit weight, fruit volume, marketable fruit yield per plant and ascorbic acid.

\section{Introduction}

Tomato (Solanum lycopersicum L.) $(2 \mathrm{n}=2 \mathrm{x}$ $=24$ ) probably originated in Peru-Ecuador, region (Rick,1990) is a herbaceous, typical day neutral plant of warm season. Tomato grown in a variety of climatic conditions and has versatile uses as fresh vegetable or processed product. Tomato being a self pollinated crop has sufficient variability in its germplasm that raises an enormous potential for heterosis breeding.

Combining ability analysis is one of the powerful tools available to estimate the combining ability effects and aids in selecting the desirable parents and crosses for the exploitation of heterosis and is studied as, general combining ability (GCA) and specific combining ability (SCA) as defined by Sprague and Tatum (1942). They stated that GCA effects were due to additive type of gene action that enables the breeders to exploit the existing variability in the breeding materials and identify individual genotypes having desirable attributes while, specific combining ability (SCA) effects are due to non-additive (dominant or epistatic) gene action that determines heterotic patterns among populations or inbred lines and 
identify promising single crosses and to assign inbred lines into heterotic groups. Diallel cross analysis proposed by Griffing (1956) is the appropriate and specific approach for the identification and selection of superior genetic material and the measurement of GCA and SCA effects helps in deciding the next phase of breeding programme. Therefore, the present research was undertaken with the objective to study the GCA and SCA in genotypes and their cross combinations for yield and quality characters.

\section{Materials and Methods}

Six diverse tomato cultivars/lines viz, AVTO9001, LC-9, Solan Lalima, Sioux, Arka Meghali and LC-4 crossed in a $6 \times 6$ half diallel fashion to obtain fifteen cross combinations. The seedlings of parents, raised in March-2016, were transplanted to attempt crossing and generate $\mathrm{F}_{1}$ 's. The fifteen $\mathrm{F}_{1}$ 's along with their parents and one check cultivar $\mathrm{F}_{1}$ hybrid Arka Rakshak were planted in December-2016 for their evaluation. The experiment was laid out in Randomized Complete Block Design (RCBD) with three replications. There were 6 plants of each entry in each replication in a plot of $1.2 \times 1.35 \mathrm{~m}^{2}$ with a spacing of $60 \mathrm{~cm} \times 45 \mathrm{~cm}$. The combining ability analysis for parental genotypes and their crosses were carried out following Method 2 and Model 1 of Griffing (1956).

\section{Results and Discussion}

The GCA and SCA effects for parents and crosses over the various traits of this experimental study have been described character-wise in Table 1 and 2, under the following heads:

\section{Plant height (cm)}

Sioux (10.75), LC-4 (8.85) and Solan Lalima (2.03) were identified as good general combiners while, nine cross combinations were well performing combiners with significant positive SCA estimates involving good $\times$ poor, average $\times$ good, poor $\times$ good and good $\times$ good, as general combiners. As good cross combinations are coming irrespective of general combining ability values of parents therefore, hybridization experiments may provide sufficient weightage to poor combiners while selecting parents for improvement of the trait. These findings are in line with the results of Kumar et al., (2013) for GCA effects and with Gautam et al., (2016)) for SCA studies.

\section{Number of fruit clusters per plant}

All the parents were average general combiners for number of fruit clusters per plant and SCA studies reveal that six specific cross combinations viz, LC-9 $\times$ Solan Lalima (1.49), Sioux $\times$ Arka Meghali (1.29), AVTO$9001 \times$ LC-4 (1.25), Arka Meghali $\times$ LC-4 (1.24), Solan Lalima $\times$ Sioux (1.15) and Solan Lalima $\times$ Arka Meghali (1.15) to be good specific combiners. All these superior crosses involved average $x$ average general combiners. Similar trend was noticed by Shankar et al., (2013) for SCA effects.

\section{Number of fruits per cluster}

All the parents were average general combiners due to their non-significant GCA effects but despite of that three cross combinations, Solan Lalima $\times$ LC-4(1.94), Sioux $\times$ Arka Meghali (1.75) and AVTO9001× Sioux (1.39) were good specific combiners for this trait due to their significant positive SCA effects.

These results for SCA find support from Kumar and Gowda (2016), Sharma and Sharma (2010) and for GCA with the findings of Kumar et al., (2013) and Kumar and Gowda (2016). 


\section{Number of fruits per plant}

Only one parent was poor general combiner i.e., LC-4(-3.68) due to its significant negative GCA effects, remaining all the five parents were the average general combiners for number of fruits per plant. Among fifteen cross combinations, six cross combinations were good specific cross combinations as reflected by their significant positive SCA effects involving average $\times$ average and average $x$ poor as general combiners. These studies for GCA are in accordance with the findings of Kumar et al., (2013), Gautam et al., (2016) and for SCA with Gautam et al., (2016) and Kumar and Gowda (2016).

\section{Fruit length (mm)}

For fruit length two parents, LC-9 (0.23) and AVTO-9001 (0.18) were good general combiners with their significant positive GCA effects. Three parents (Sioux, 0.04, Solan Lalima -0.16, Arka Meghali -0.07) were average general combiners and only one parent was poor general combiner i.e., LC-4(0.22 ). Out of fifteen cross combinations, three cross combinations $v i z$, LC-9 $\times$ Arka Meghali (0.64), AVTO-9001 $\times$ Sioux (0.45) and Solan Lalima $\times$ Sioux $(0.42)$ were good specific combinations and these superior cross combinations involved good $x$ average and average $x$ average general combiners. A good general combiner upon crossing with good or average combiner is most likely to provide a potential heterotic combination. These results are similar to the findings of Pandey et al., (2006) and Sharma and Sharma (2010).

\section{Fruit breadth (mm)}

Among all the parents, five parents viz, Sioux (0.15), AVTO-9001(0.15), LC-9 (0.03), Solan Lalima (-0.14) and Arka Meghali (-0.02) were average general combiners while remaining one parent was poor general combiner due to its negative significant GCA effects i.e., LC-4 $(-0.18)$. Out of fifteen cross combinations only three cross combinations were good specific combiners and all these three cross combinations involved average $\times$ average as general combiners so there are at most possibility that average general combiners can give raise to good specific combiners. With respect to GCA and SCA effects, similar results were obtained by Pandey et al., (2006) and Sharma and Sharma (2010).

\section{Average fruit weight (g)}

The good GCA for average fruit weight was found in only two parents viz, Sioux (2.80) and AVTO-9001 (1.51). Six cross combinations out of fifteen found to be good specific combiners for this trait involving good $\times$ good, poor $\times$ good, good $\times$ average, average $x$ average, average $x$ poor and average $x$ good general combiners sometimes the involvement of poor as well as average general combiners proves to be best for getting the significant results apart from good general combiners involvement. The results for GCA and SCA are in accordance with the findings of Sharma and Sharma (2010), Kumar et al., (2013) and Agarwal et al., (2014).

\section{Fruit volume (mL)}

The estimates of GCA effects for fruit volume revealed three parents namely, AVTO9001(9.38), Sioux (7.92) and Arka Meghali (0.88) to be good general combiners due to their positive significant GCA effects while, remaining three parents were poor general combiner. Seven cross combinations proved to be good specific cross combinations for fruit volume because of their positive significant SCA effects involving poor $x$ good, good $\times$ good, good $\times$ good as general combiners. 
Int.J.Curr.Microbiol.App.Sci (2019) 8(2): 1725-1730

Table.1Estimates of general combining ability effect of parents for different parameters

\begin{tabular}{|c|c|c|c|c|c|c|c|c|c|c|c|c|c|c|c|}
\hline Parents & $\begin{array}{l}\text { Plant } \\
\text { Height }\end{array}$ & $\begin{array}{l}\text { No. of Fruit } \\
\text { Clusters / plant }\end{array}$ & $\begin{array}{l}\text { No. } \\
\text { Fruits/ } \\
\text { Cluster }\end{array}$ & $\begin{array}{l}\text { No. } \\
\text { Fruits/ } \\
\text { Plant }\end{array}$ & $\begin{array}{l}\text { Fruit } \\
\text { Length }\end{array}$ & $\begin{array}{c}\text { Fruit } \\
\text { Breadth }\end{array}$ & $\begin{array}{l}\text { Average } \\
\text { fruit } \\
\text { weight }\end{array}$ & $\begin{array}{c}\text { Fruit } \\
\text { Volume }\end{array}$ & $\begin{array}{c}\text { Marketable } \\
\text { fruit yield / } \\
\text { plant }\end{array}$ & $\begin{array}{c}\text { Harvest } \\
\text { Duration }\end{array}$ & $\begin{array}{l}\text { Shelf } \\
\text { life }\end{array}$ & $\begin{array}{l}\text { Pericarp } \\
\text { thickness }\end{array}$ & TSS & $\begin{array}{c}\text { Ascorbic } \\
\text { Acid }\end{array}$ & Whitefly \\
\hline AVTO-9001 & -0.69 & 0.07 & 0.44 & 2.68 & $0.18 *$ & 0.15 & $1.51^{*}$ & $9.38 * *$ & 0.14 & 0.24 & -0.17 & 0.04 & -0.12 & -0.29 & -0.74 \\
\hline LC-9 & $-2.44 * *$ & -0.01 & -0.29 & -0.62 & $0.23 *$ & 0.03 & 0.45 & $-3.30^{* *}$ & -0.02 & 0.61 & 1.17 & 0.04 & 0.27 & -0.88 & 0.22 \\
\hline Solan Lalima & $2.03 * *$ & 0.11 & -0.23 & 0.42 & -0.16 & -0.14 & $-1.95 *$ & $-5.29 * *$ & -0.08 & -0.14 & -0.26 & 0.00 & -0.13 & 0.64 & $1.78^{*}$ \\
\hline Sioux & $10.75^{* *}$ & -0.01 & 0.21 & 0.83 & 0.04 & 0.15 & $2.80 * *$ & $7.92 * *$ & $0.26^{*}$ & -0.06 & $0.76^{* *}$ & 0.00 & 0.16 & 1.60 & $-1.79 *$ \\
\hline Arka Meghali & $-18.49 * *$ & -0.10 & 0.26 & 0.37 & -0.07 & -0.02 & 0.08 & $0.88 * *$ & 0.01 & -0.10 & $-1.05^{* *}$ & $-0.07 * *$ & -0.24 & -0.28 & -0.50 \\
\hline LC-4 & $8.85 * *$ & -0.05 & -0.38 & $-3.68 *$ & $-0.22 *$ & $-0.18^{*}$ & $-2.88 * *$ & $-9.59 * *$ & $-0.30^{*}$ & -0.56 & $-0.45^{* *}$ & -0.01 & 0.05 & -0.79 & 1.03 \\
\hline Se (gi) & 0.287 & 0.156 & 0.224 & 1.339 & 0.068 & 0.064 & 0.422 & 0.115 & 0.081 & 1.070 & 0.154 & 0.017 & 0.122 & 0.475 & 0.534 \\
\hline SE (gi-gj) & 0.044 & 0.241 & 0.346 & 2.076 & 0.105 & 0.197 & 0.207 & 0.179 & 0.126 & 1.182 & 0.239 & 0.052 & 0.189 & 0.738 & 0.783 \\
\hline CD at $5 \%$ & 0.727 & 0.394 & 0.568 & 3.394 & 0.171 & 0.161 & 1.069 & 0.292 & 0.206 & 2.711 & 0.390 & 0.043 & 0.309 & 1.205 & 1.353 \\
\hline
\end{tabular}
$*, * *$ significant at $5 \%$ and $1 \%$ level, respectively

Table.2 Estimates of specific combining ability effect of cross combinations for different parameters

\begin{tabular}{|c|c|c|c|c|c|c|c|c|c|c|c|c|c|c|c|}
\hline $\begin{array}{c}\text { Cross } \\
\text { Combinations }\end{array}$ & $\begin{array}{l}\text { Plant } \\
\text { Height }\end{array}$ & $\begin{array}{c}\text { No of Fruit } \\
\text { Clusters } \\
\text { /plant }\end{array}$ & $\begin{array}{c}\text { No } \\
\text { Fruits / } \\
\text { Clusters }\end{array}$ & $\begin{array}{c}\text { No } \\
\text { Fruits/ } \\
\text { Plant }\end{array}$ & $\begin{array}{c}\text { Fruit } \\
\text { Length }\end{array}$ & $\begin{array}{c}\text { Fruit } \\
\text { Breadth }\end{array}$ & $\begin{array}{c}\text { Average } \\
\text { fruit } \\
\text { weight }\end{array}$ & $\begin{array}{c}\text { Fruit } \\
\text { Volume }\end{array}$ & $\begin{array}{c}\text { Marketable } \\
\text { fruit yield/ } \\
\text { plant }\end{array}$ & $\begin{array}{c}\text { Harvest } \\
\text { Duration }\end{array}$ & Shelf life & $\begin{array}{l}\text { Pericarp } \\
\text { thickness }\end{array}$ & TSS & $\begin{array}{l}\text { Ascorbic } \\
\text { acid }\end{array}$ & Whitefly \\
\hline AVTO-9001 × LC-9 & $-1.58 * *$ & -0.43 & $-1.68 * *$ & $-12.65 * *$ & -0.24 & -0.08 & $9.84 * *$ & $-1.11 * *$ & -0.23 & -1.32 & $-0.91 *$ & -0.10 & $-1.23 * *$ & -0.92 & $3.22 *$ \\
\hline AVTO-9001 × Solan Lalima & $-20.41^{* *}$ & 0.5 & 0.53 & 5.28 & $-0.46^{*}$ & -0.03 & $-4.86^{* * *}$ & $-7.9 * *$ & 0.06 & $2.60^{*}$ & -0.62 & 0.01 & $1.52 * *$ & 2.68 & 2.57 \\
\hline AVTO-9001 $\times$ Sioux & $-4.43 * *$ & -0.16 & $1.39 * *$ & 7.26 & $0.45^{*}$ & 0.19 & $10.72 * *$ & $19.72 * *$ & $1.11 * *$ & 1.43 & 0.51 & 0.01 & -0.44 & $3.85^{* * *}$ & -0.04 \\
\hline AVTO-9001 × Arka Meghali & $0.22 *$ & 0.61 & -0.51 & 0.94 & 0.29 & $0.41 *$ & $-0.55^{* *}$ & $13.08^{* *}$ & 0.34 & 1.18 & -0.09 & 0.05 & 0.35 & 1.66 & $-5.42 * *$ \\
\hline AVTO-9001 × LC-4 & $20.6 * *$ & $1.25 * *$ & 0.82 & $13.44 * *$ & -0.23 & 0.02 & $-9.76 * *$ & $13.55^{* * *}$ & 0.42 & 0.64 & 0.34 & $-0.13 * *$ & -0.13 & 1.22 & 1.63 \\
\hline LC-9 $\times$ Solan Lalima & $2.25 * *$ & $1.49 * *$ & -0.17 & $8.11^{*}$ & 0.14 & 0.07 & $-8.52 * *$ & $-12.99 * *$ & 0.09 & $2.60 *$ & 0.71 & 0.10 & $1.95 * *$ & $3.11 * *$ & 3.13* \\
\hline LC-9 $\times$ Sioux & $16.8^{* * *}$ & 0.53 & 1.12 & $9.86^{*}$ & -0.25 & $0.41 *$ & $1.47 * *$ & $21.93 * *$ & 0.65 & $2.18^{*}$ & $1.48^{* * *}$ & 0.02 & 0.92 & 1.93 & -1.34 \\
\hline LC-9 $\times$ Arka Meghali & $-11.91 * *$ & -0.28 & 0.39 & -1.44 & $0.64 * *$ & -0.03 & $7.77 * *$ & $2.05 * *$ & 0.27 & 1.30 & -0.11 & 0.02 & -0.09 & -0.56 & $-3.43 * *$ \\
\hline LC-9 $\times$ LC-4 & $-16.74^{* *}$ & -0.08 & $-1.6 * *$ & $-11.7^{* *}$ & -0.26 & -0.19 & $8.68 * *$ & $-13.07^{* *}$ & -0.08 & 1.80 & $-2.03^{* *}$ & -0.08 & -0.52 & -0.93 & 2.84 \\
\hline Solan Lalimax Sioux & 12.59 ** & $1.15^{*}$ & -0.25 & 6.56 & $0.42 *$ & $0.41^{*}$ & $9.99 * *$ & $18.7 * *$ & $0.91 * *$ & 1.85 & 0.38 & 0.08 & 0.39 & $3.42 * *$ & -1.76 \\
\hline $\begin{array}{c}\text { Solan Lalima } \times \text { Arka } \\
\text { Meghali }\end{array}$ & $19.23^{* * *}$ & $1.15^{*}$ & -0.71 & 2.45 & $-0.58 * *$ & -0.25 & $-7.21^{* *}$ & $-16.13 * *$ & -0.28 & 0.80 & 0.30 & 0.04 & -0.43 & -2.33 & $-4.40 * *$ \\
\hline Solan Lalima $\times$ LC-4 & $6.09 * *$ & 0.22 & $1.94 * *$ & $16.96^{* *}$ & -0.31 & $-0.55 * *$ & $-13.85^{* *}$ & $-17.76 * *$ & 0.17 & 1.55 & $-1.24 * *$ & 0.08 & 0.11 & -0.52 & $4.86 * *$ \\
\hline Sioux $\times$ Arka Meghali & $29.00^{* * *}$ & $1.29 * *$ & $1.75^{* *}$ & $25.26^{* *}$ & 0.03 & 0.07 & $-11.03^{* *}$ & $5.43 * *$ & $0.66^{*}$ & $2.47 *$ & $1.06^{*}$ & -0.01 & 0.03 & 1.76 & 2.23 \\
\hline Sioux $\times$ LC-4 & $10.02 * *$ & $-1.11 *$ & -0.57 & $-10.9^{* *}$ & $-0.87 * *$ & $-0.44 *$ & $-8.8 * *$ & $-21.63 * *$ & $-0.91 * *$ & -0.20 & -0.99 & -0.04 & -0.21 & -2.38 & $4.36 * *$ \\
\hline Arka Meghali $\times$ LC-4 & $-13.58 * *$ & $1.24 * *$ & -0.41 & $8.69 *$ & -0.04 & $-0.43 *$ & $-13.73 * *$ & $-8.26 * *$ & -0.11 & 1.89 & $-1.34 * *$ & -0.09 & -0.01 & -2.03 & 3.05* \\
\hline Se (sij) & 0.079 & 0.428 & 0.614 & 3.678 & 0.186 & 0.175 & 0.037 & 0.032 & 0.223 & 1.048 & 0.423 & 0.046 & 0.336 & 1.308 & 1.388 \\
\hline SE (sij-sjk & 0.012 & 0.638 & 0.918 & 5.489 & 0.277 & 0.260 & 0.055 & 0.047 & 0.333 & 1.564 & 0.632 & 0.069 & 0.501 & 1.952 & 2.072 \\
\hline CD at $5 \%$ & 0.162 & 0.878 & 1.261 & 7.553 & 0.382 & 0.359 & 0.075 & 0.065 & 0.458 & 2.152 & 0.869 & 0.095 & 0.690 & 2.685 & 2.850 \\
\hline
\end{tabular}
$*, * *$ significant at $5 \%$ and $1 \%$ level, respectively 


\section{Marketable fruit yield per plant $(\mathrm{Kg})$}

This is the important trait in farmer point of view and GCA studies found only one parent, Sioux (0.26) to be the good general combiner. Good specific cross combinations for this trait were AVTO-9001 $\times$ Sioux (1.11), Solan Lalima $\times$ Sioux $(0.91)$ and Sioux $\times$ Arka Meghali (0.66) because of their positive significant SCA effect, involving average $x$ good and good $x$ average as general combiners. Similar results were observed by Kumar et al., (2013), Shankar et al., (2013) and Agarwal et al., (2014) for GCA and SCA.

\section{Harvest duration (days)}

All the parents were average general combiners while, SCA studies figured out four cross combinations viz, LC-9 $\times$ Solan Lalima (2.60), AVTO-9001 $\times$ Solan Lalima (2.60), Sioux $\times$ Arka Meghali (2.47) and LC$9 \times$ Sioux (2.18) to be good specific combiners despite of all general combiners with average GCA effects. Significance is the indication of this trait in desirable direction with high heterotic response. A similar result for SCA was reported by Sharma and Sharma (2010) and Gautam et al., (2016) for GCA effects.

\section{Shelf life (days)}

Shelf life is the factor impacting quality and among the parents Sioux (0.76) was the only good general combiner and LC-9 $\times$ Sioux (1.48) and Sioux $\times$ Arka Meghali (1.06) were good specific cross combinations involving average $\times$ good and good $\times$ poor respectively. These findings were also observed by Kumar and Gowda (2016).

\section{Pericarp thickness (mm)}

Arka Meghali (-0.07) was the only poor general combiner for pericarp thickness and remaining all the five parents were average general combiners. SCA studies designated only AVTO-9001 × LC-4 (-0.13) to be poor cross combination for pericarp thickness while rest all the cross combinations were average specific combiner. These findings are in close relation with the findings of Aisyah et al., (2016) for GCA and with Shankar et al., (2013), Gautam et al., (2016) and Aisyah et al., (2016) for SCA.

\section{Total soluble solids $\left({ }^{0} \mathrm{~B}\right)$}

For TSS all the parents were average general combiners and only two cross combinations were good specific combiners i.e., LC-9 $\times$ Solan Lalima (1.95) and AVTO-9001 $\times$ Solan Lalima (1.52) due to their positive significant SCA effects while, one cross was poor specific combiner AVTO-9001 × LC-9(1.23). Remaining all the crosses were average specific combiners due to their nonsignificant SCA effects. Similar findings was obtained Kumar et al., (2013) for SCA studies and for GCA studies with Shankar et al., (2013) and Agarwal et al., (2014).

\section{Ascorbic acid (mg/100g)}

All the parents were average general combiners for ascorbic acid. Three cross combinations were good specific combiners i.e., AVTO-9001× Sioux (3.85), Solan Lalima $\times$ Sioux (3.42), LC-9 $\times$ Solan Lalima (3.11) because of their positive significant SCA effects while remaining all the cross combinations were average specific combiners due to their non-significant SCA effects. The studies for SCA get the support of literature from Kumar et al., (2013) and for GCA with Shankar et al., (2013) and Gautam et al., (2016).s

\section{Whitefly infestation (\%)}

Among the cross combinations three cross combinations, AVTO-9001 $\times$ Arka Meghali (5.42), Solan Lalima $\times$ Arka Meghali (-4.40) 
and LC-9 $\times$ Arka Meghali (-3.43) were good specific cross combiners which involved average $x$ average, poor $\times$ average and average $x$ average as general combiners despite of only Sioux (-1.79) being good combiner was unable to express in any of the $\mathrm{F}_{\mathbf{1}}$ 's.

In conclusion, Sioux was the best general combiner with high significant positive GCA effects for most of the traits and inspite of parents being average general combiners for most of the traits Solan Lalima x Sioux emerged out as best specific combiner with high significant positive SCA effects for Plant height $(\mathrm{cm})$, fruit length $(\mathrm{mm})$, fruit breadth $(\mathrm{mm})$, fruit volume $(\mathrm{mL})$, average fruit weight $(\mathrm{g})$, number of fruit clusters per plant, marketable fruit yield $(\mathrm{Kg})$ and ascorbic acid $(\mathrm{mg} / 100 \mathrm{~g})$.

\section{References}

Agarwal, A., Arya, D.N., Ranjan, R., and Ahmed, Z. 2014.Heterosis,combining ability and gene action for yield and quality traits in tomato (Solanum lycopersicum L.). Helix. 2: 511- 515.

Aisyah, S.I., Wahyuni, S., Syukur, M., and Witono, J.R. 2016. The estimation of combining ability and heterosis effect for yield and yield components in tomato (Solanum lycopersicum Mill.) at lowland. Ekin Journal. 2(1):23-29.

Gautam, N., Kumar, M., Kumar, S., Vikram, A., Dogra, R. K. and Bharat, N. 2016.Combining ability analysis and gene action for yield and its contributing traits in tomato (Solanum lycopersicum L.) under North Western Himalayan region. Ecology Environment \& Conservation. 22 (1): 345-349.

Griffing, B., 1956. Concepts of general and specific combining ability in relation to diallel crossing systems. Australian Journal of Biology Sciences. 9: 463493.

Kumar, S., and Gowda, P.H.R. 2016. Estimation of heterosis and combining ability in tomato for fruit shelf life and yield component traits using line $\mathrm{x}$ tester method. International Journal of Agronomy and Agricultural Research. 9(3):10-19.

Kumar, R., Srivastava, K., Singh, N.P., Vasistha, N. K., Singh, R. K., and Singh, M. K. 2013. Combining Ability Analysis for Yield and Quality Traits in Tomato (Solanum lycopersicum L.). Journal of Agricultural Science. 5(2): 213-218.

Pandey, S.K., Dixit, J., Pathak, V.N., and Singh, P. K. 2006. Line $x$ tester analysis for yield and quality characters in tomato (Solanum lycopersicum Mill.). Vegetable Science. 33(1): 13-17.

Rick, C.M., and Holle, M. 1990. Andean Lycopersicon esculentum var. cerasiforme: genetic variation and its evolutionary significance. Journal of Economic Botany. 43(3): 69-78.

Shankar, A., Reddy, R.V.S.K, Sujatha, M., and Pratap, M. 2013. Combining ability and gene action studies for yield and yield contributing traits in tomato (Solanum lycopersicum L.). Helix. 6: 431-43.

Sharma, D., and Sharma, H.R. 2010. Combining ability analysis for yield and other horticultural traits in tomato. Indian Journal of Horticulture. 67(3): 402-405.

Sprague, G.F., and Tatum, L.A. 1942. General vs. specific combining ability in single crosses of corn. Journal of the American Society of Agronomy. 34: 923-932.

\section{How to cite this article:}

Veena, A.M., Ajaya Paliwal, J.C. Thilak, Himani Rana and Pant, S.C. 2019. Combining Ability Studies in Tomato (Solanum lycopersicum L.) in Mid Hills of Uttarakhand. Int.J.Curr.Microbiol.App.Sci. 8(02): 1725-1730. doi: https://doi.org/10.20546/ijcmas.2019.802.203 